$\underline{\xi}=-m$

\title{
Evaluation of anti-oxidant status in-vitro and in-vivo in hydro-alcoholic extract of Eugenia caryophyllus
}

\author{
Roma Ghai $^{1 *}$, K.Nagarajan $^{2}$, Jitendra Singh ${ }^{3}$, Shivam Swarup ${ }^{4}$, Minu Kesheri ${ }^{5}$ \\ ${ }^{I}$ Assistant Professor, Department of Pharmacology, KIET School of Pharmacy, $13 \mathrm{Km}$. Stone, \\ Ghaziabad Meerut Road, Ghaziabad-201206, Delhi-NCR, India \\ ${ }^{2}$ Professor and Head, Department of Pharmaceutical Chemistry, KIET School of Pharmacy, 13 Km. Stone, \\ Ghaziabad Meerut Road, Ghaziabad-201206, Delhi-NCR, India \\ ${ }^{3}$ Research Scholar, Faculty of Pharmacy, Jamia Hamdard, New Delhi-110062, India \\ ${ }^{4}$ Research Scholar, Department of Pharmaceutics, KIET School of Pharmacy, $13 \mathrm{Km}$. Stone, \\ Ghaziabad Meerut Road, Ghaziabad-201206, Delhi-NCR, India \\ ${ }^{5}$ Assistant Professor \& Head of Research and Consultancy, Department of Life Sciences, \\ Shridhar University, Pilani-333031, India \\ *Corresponding author E-mail: roma.ghai@ kiet.edu
}

\begin{abstract}
Free radicals mediated oxidative stress is the major risk factor for many chronic diseases like atherosclerosis, diabetes mellitus, arthritis, cancer, ageing and neurodegenerative diseases. Therapy with anti-oxidants is gradually gaining lot of importance for treatment of such diseases. Hydro-alcoholic extract of Eugenia caryophyllus was studied for its in-vivo antioxidant activity using two different animal models viz. Triton induced hyperlipidemia and High fat diet induced hyperlipidemia. Total phenolic content and total flavonoid content, DPPH assay was also carried out for in vitro anti-oxidant efficacy. Total protein, lipid peroxidation (MDA), reduced glutathione, superoxide dismutase and catalase were evaluated in the liver tissue in Triton induced hyperlipidemia and diet induced hyperlipidemia models. The study findings indicated significant in-vivo and in-vitro antioxidant property that may be related to the amount of polyphenols and flavonoids present in the extract. These results clearly indicate that Eugenia caryophyllus is effective against free radical mediated oxidative stress.
\end{abstract}

Keywords: DPPH Assay; Eugenia caryophyllus; Hyperlipidemia; Lipid Peroxidation; Triton Induced.

\section{Introduction}

The free radicals are produced during the normal metabolic functions of biochemical pathways and also they can be acquired from the environment. Free radicals contain unpaired electrons. These include reactive oxygen species (ROS), like superoxide radical $\left(\mathrm{O}^{2-}\right)$, hydroxyl radical $(. \mathrm{OH})$ and reactive nitrogen species (RNS). However, these excess free radical generating from endogenous or exogenous sources are responsible for causing oxidative damage to various cellular molecules such as lipids, protein and nucleic acids, hence attacking the unsaturated fatty acids in the biomembranes which causes peroxidation of membrane lipids, a cardinal sign of inflammatory process, decrease in membrane fluidity and reduction of enzyme and receptor activity and damage to membrane protein and damage to DNA which finally triggers the cell inactivation and death. Research has shown that free radical mediated oxidative stress is among the major causative factors in induction of many chronic and degenerative diseases like atherosclerosis, ischemic heart diseases, ageing, diabetes mellitus, cancer, immune-suppression, neurodegenerative diseases and others (Mittal et al. 2014), and thus are involved in the initiation phase of some degenerative diseases (Zorov et al. 2014), and also responsible for ageing. The major defense against free radicals induced damage can be found in the natural antioxidants (Poljsak et al. 2011). Antioxidants prevents free radicals from doing harm to our
DNA, proteins and cells by donating electrons to stabilize and neutralize the harmful effects of free radicals (Mittal et al. 2014). The beneficial effects of antioxidants on promoting health is believed to be achieved through several probable mechanisms, such as direct reaction with and scavenging free radicals, chelation of transition metals, reduction of peroxides, and stimulation of the anti-oxidative enzyme defense system. Thus anti-oxidants can be used to oppose the harmful and pathological actions of free radicals and thereby restore the normal physiological systems of the body. The antioxidants in use are either derived naturally from plants or by synthetic means. Although several synthetic antioxidants such as butylated hydroxylanisole (BHA) and butylated hydroxyl toluene (BHT) are available, they are quite unsafe and reported to be toxic (Poljsak et al. 2013). Natural antioxidants are acceptable with the consumers as they are considered to be safe. Ascorbic acid, carotenoids and phenolic compounds are naturally occurring effective antioxidants (Kataki et al. 2012). Plants have been reported to exhibit antioxidant activity due to the presence of antioxidant compounds such as phenolics, proanthocyanidins and flavonoids.

Eugenia caryophyllus is a small ever-green tree belonging to the botanical family Myrtaceae (subfamily: Myrtoideae and tribe: Syzgieae) and also known as Syzygium aromaticum (L.) Merr. \& L. M. Perry. It is one of the most ancient and valuable spices of the Orient, with its origin as old as the first century, before Christ. The flower buds contain 15 to 20 percent of essential oil contain- 
ing major components i.e. Eugenol (70-85\%); followed by eugenyl acetate $(15 \%)$ and beta caryophyllin $(5-12 \%)$. The other constituents of oil include methylamylketone, methyl salicylate, alpha and beta humulene, benzaldehyde, chavicol, gallotanic acid, caryophyllin. It is broadly used in cooking, food processing, pharmacy, perfumery and cosmetics and is a popular remedy for dental and respiratory disorders like asthma, digestive system ailments like dyspepsia, gastritis and diarrhea in traditional medicine. It is also used as antipyretic, antiemetic, anxiolytic, myorelaxant, decongestant, anti-inflammatory, and hypnotic. It represents one of the Mother Nature's premier antiseptic. It is used to treat broad spectrum of ailments as it possesses antifungal, antiviral, antimicrobial properties (Cai \& Wu, 1996; Chaieb et al. 2007). It was found that both eugenol and acetyleugenol were more potent in inhibiting platelet aggregation induced by arachidonate, adrenaline and collagen (Srivastava 1993). Medicinal uses of clove reveal that it increases memory retention, relieves depression and possess anticonvulsant activity also (Pourgholami et al 1999, Singh et al. 2012). Clove is also known to slow down macular degeneration as it prevents the breakdown of docosahexaenoic acid, which preserves vision in elderly people. The present study was aimed to investigate the effects of hydro-alcoholic extract of Eugenia caryophyllus, on the anti-oxidant enzymes in Wistar rats.

\section{Materials and methods}

Triton X-100,Quercetin was obtained from Sigma-Aldrich, USA Atorvastatin was obtained from Alkem Research Centre, Navi Mumbai. 1,1, Diphenyl-2-picryl hydrazyl (DPPH) was obtained from Hi Media laboratories (P)Ltd., Mumbai, India. Ethanol was purchased from Merck Chemicals, Germany. Ascorbic acid and al other chemicals and solvents used in the present study were of analytical grade and were purchased from Qualigens fine chemicals, Mumbai \& Central Drug House, New Delhi, India.

\subsection{Collection and identification of plant material}

The flower buds of Eugenia caryophyllus were collected from an authorized vendor, 'Global Herbs' and then authenticated by Professor Mohammed Ali, Department of Pharmacognosy, Faculty of Pharmacy, Jamia Hamdard, New Delhi. A voucher specimen coded PRL/JH/11/01 has been deposited in the Jamia Hamdard for future reference.

\subsection{Preparation of plant extract}

The flower buds of Eugenia caryophyllus were dried under shade at room temperature and reduced to coarse powder. About $250 \mathrm{~g}$ of powder was subjected to cold maceration with $500 \mathrm{ml}$ of $70 \%$ ethanol for 7 days in an iodine flask at room temperature with in between stirring \& shaking. After 7 days, it was filtered through Whatman filter paper 1 and the filtrate was then concentrated on water bath to obtain a dark brownish residue. The percentage yield obtained was $25 \%$. The aqueous ethanolic extract was further subjected to qualitative tests for the identification of various phytoconstituents like carbohydrates, saponins, glycosides, alkaloids, flavonoids, phenols and phytosterols

\subsection{Estimation of total phenolic content}

Total phenolic content was determined using the Folin- Ciocalteu method with some modifications. Stock solution of aqueous ethanolic extract was prepared to get a final concentration of $1 \mathrm{mg} / \mathrm{ml}$. In this method, extract of $0.1 \mathrm{~g}$ was weighed and dissolved in $5 \mathrm{ml}$ ethanol (95\%) then made up to $100 \mathrm{ml}$ with distilled water. $0.4 \mathrm{ml}$ of the stock solution was taken and added with $2 \mathrm{ml}$ of $50 \%$ Folin - Ciocalteau reagent. The solution mixture was allowed to react for $5 \mathrm{~min}$. The mixture was further reacted with $4 \mathrm{ml}$ of $5 \%$ $\mathrm{Na}_{2} \mathrm{CO}_{3}$ and placed in dark for $1 \mathrm{hr}$. The absorbance was measured at $725 \mathrm{~nm}$ using Shimadzu $1800 \mathrm{UV}$ spectrophotometer. The ab- sorbance values were compared with gallic acid standard in the range between $10-100 \mu \mathrm{g} / \mathrm{ml}$. All experiments were done in triplicate and the results obtained were expressed in $\mathrm{mg}$ of GAE/ 100mg extract (Olayinka \& Anthony, 2009). The concentration of total phenols was expressed as $\mathrm{mg} / \mathrm{g}$ of extract.

\subsection{Estimation of total flavonoid content}

The concentration of flavonoids was determined using spectrophotometric method. The sample contained $1 \mathrm{ml}$ of Methanolic extract of $(1 \mathrm{mg} / \mathrm{ml})$ and $1 \mathrm{ml}$ of $2 \% \mathrm{Al}_{2} \mathrm{Cl}_{3}$ solution dissolved in methanol. The samples were incubated for an hour at room temperature. The absorbance was determined at $415 \mathrm{~nm}$ using Shimadzu 1800, UV spectrophotometer. The samples were prepared thrice and the mean value of absorbance was obtained. Also, the similar procedure was followed for plotting the standard curve of Quercetin. Concentration of flavonoids in extract was expressed in terms of Quercetin equivalent (mg of $\mathrm{Qu} / \mathrm{g}$ of extract).

\subsection{DPPH (1, 1-diphenyl-2-picryl-hydrazyl) radical scavenging assay}

The free radical scavenging activity of the $70 \%$ aqueous ethanolic extract of Eugenia caryophyllus and ascorbic acid as positive control was measured in terms of hydrogen donating or radical scavenging ability using the stable radical DPPH. $2 \mathrm{ml}$ of each extract and control at various concentrations $(100,50,25,12.5,6.25$, $3.125,1.625$ and $0.812 \mathrm{ug} / \mathrm{ml}$ ) were added to $3 \mathrm{ml}$ of freshly prepared DPPH solution $(0.004 \%)$ in methanol.The reaction was allowed for $30 \mathrm{~min}$ and absorbance was measured at $515 \mathrm{~nm}$ using a spectrophotometer (Shimadzu $1800 \mathrm{UV}$-visible spectrophotometer). The degree of decolorization of DPPH from purple to yellow indicated the scavenging efficiency of the extract (Olayinka \& Anthony, 2009). The percentage inhibition of DPPH free radical scavenging activity was calculated using the following equation:

$\%$ DPPH Inhibition $=\frac{\text { Abs of Control }\left(\mathrm{A}_{\mathrm{DPPH}}\right)-\mathrm{Abs} \text { of Test }\left(\mathrm{A}_{\mathrm{SAMPLE}}\right)}{\mathrm{Abs} \text { of Control }\left(\mathrm{A}_{\mathrm{DPPH}}\right)} \times 100$

Where:

$\mathrm{A}_{\mathrm{DPPH}}(\mathrm{Control})=$ Absorbance $(\mathrm{DPPH})$

$\mathrm{A}_{\text {sample }}($ Test $)=$ Absorbance $($ extract/ascorbic acid $)$

The $\%$ inhibition data was then plotted against log concentration fitted in a graph and $\mathrm{IC}_{50}$ (half-maximal inhibitory concentration) value was calculated by linear regression analysis.

\subsection{Experimental animals}

60 Albino Wistar rats of either sex weighing between 150-225 gms were used for the study. During the course of the experiment, the animals were fed with standard pellet diet ad libitum and had free access to water. Animal experiments were approved by the IAEC (IAEC /KSOP/02/2013-14 dated 18.10.13)

\subsection{Experimental procedure}

The animals were divided into two sets of 30 animals each. In the first set of experiment, the animals were divided into five groups of six animals each, which are as follows:

Group 1: Represented control that received vehicle (1\% CMC) orally for 7 days. Group 2: Rats received Triton-100X i.p. at a dose of $400 \mathrm{mg} / \mathrm{kg}$ b.wt. Group $3 \& 4$ receiving suspension of plant extract at the dose of $200 \mathrm{mg} / \mathrm{kg} \& 400 \mathrm{mg} / \mathrm{kg}$ b.wt respectively orally for 7 days. Group 5: Rats received standard drug Atorvastatin $10 \mathrm{mg} / \mathrm{kg}$ b.wt, once daily, orally for 7 days.

In the second set of group, animals were again divided into five groups of six animals each, as below.

Group I (Control): Standard chow diet: Group II: High Fat Diet; Group III \& IV: High fat diet + aqueous ethanolic extract of $E u$ genia caryophyllus p.o. ( $200 \mathrm{mg} / \mathrm{kg}$ b.wt \& $400 \mathrm{mg} / \mathrm{kg}$ b.wt respectively) Group V: High fat diet + standard drug atorvastatin p.o. (10 
$\mathrm{mg} / \mathrm{kg}$ b.wt). Treatment with the extract and Atorvastatin was carried out for the next six weeks.

\subsubsection{Composition of High fat diet}

HFD was made by mixing wheat powder $(67.5 \mathrm{~g})$, Corn powder(62.5g), Barley powder (37.5g), Milk powder(37.5g), Animal fat $(25 \mathrm{~g})$, Calcium chloride(2.5g), Salt $(2.5 \mathrm{~g})$, Coconut oil(10ml), Vanaspati (10ml), Cholic acid(2g), Cholesterol(2g), Sugar(20g) and Vit.B12(1 tablet). The wet dough was dried at room temperature and rolled into small balls for feeding the animals.

Rats of group II were fed with high fat diet for six weeks orally. Group III and IV were fed with the hydroalcoholic extract of $E u$ genia caryophyllus for six weeks at the dose of $200 \mathrm{mg} / \mathrm{kg}$ and $400 \mathrm{mg} / \mathrm{kg}$ b.wt respectively while on high fat diet. Group V were fed with standard drug atorvastatin $(10 \mathrm{mg} / \mathrm{kg}$ b.wt). Both the extract and atorvastatin were suspended in $1 \%$ gum acacia separately and fed to the respective rats by oral intubation. At the end of 6 weeks, all the animals were sacrificed by cervical decapitation after overnight fasting. Liver was cleared of adhering fat, weighed accurately and used for the preparation of homogenate which was used for estimation of in vivo anti-oxidant enzymes and estimation of lipid peroxidation.

\subsection{Preparation of tissue homogenate}

In chilled normal saline, excised livers were perfused to remove all the blood cells. Then they were cut down into small pieces, placed in $0.1 \mathrm{M}$ phosphate buffer $(\mathrm{pH} 7.4)$ and homogenized using remi homogenizer to obtain $20 \%$ homogenate. The homogenate thus obtained was centrifuged at $3000 \mathrm{rpm}$ for $15 \mathrm{~min}$ at $4^{\circ} \mathrm{C}$ and the supernatant was collected in an Eppendorf tube (NouroozZadeh et al. 1995).

\subsection{Tissue estimations}

\subsubsection{Determination of protein content}

The protein content was measured according to the method of Lowry et al. $1951.0 .1 \mathrm{ml}$ tissue supernatant was mixed properly with $0.9 \mathrm{ml}$ of DDW (Double distilled H2O) and then added $5 \mathrm{ml}$ of working alkaline solution in it. It was incubated for $10 \mathrm{~min}$ at room temperature and then added $0.5 \mathrm{ml}$ ice cold folin (Folinciocalteau) reagent. Again at room temperature incubated the solution and absorbance measured at $750 \mathrm{~nm}$ against reagent blank The protein content in the samples was extrapolated from the standard curve of Bovine serum albumin (Absorbance against concentration) in the concentration range of $10 \mu \mathrm{g}-100 \mu \mathrm{g}$.

\subsubsection{Determination of lipid peroxidation (MDA content)}

Lipid peroxidation in the tissue was estimated by the method of Ohkawa, 1979. Malondialdehyde (MDA), produced during peroxidation of lipids, served as an index of lipid peroxidation. In this method MDA reacts with thiobarbituric acid to generate a coloured product, whose absorbance is read at $540 \mathrm{~nm}$.

The suspension medium in $1 \mathrm{ml}$ aliquot was drawn out from the tissue homogenate $0.5 \mathrm{ml}$ of TCA $(30 \%)$ was added to it followed by $0.5 \mathrm{ml}$ of $0.8 \%$ TBA reagent. The tubes were wrapped in aluminium foil and kept for 30 minutes in shaking water bath at $80^{\circ} \mathrm{C}$ of temperature. Thereafter the tubes were stored for 30minutes in cold ice water. These were subjected to centrifugation for 15 minutes at $3000 \mathrm{rpm}$. The supernatant was read for absorbance at room temperature at $540 \mathrm{~nm}$ wavelength against pre-defined blank. Blank consisted of $1 \mathrm{ml}$ distilled water, TCA and TBA in their respective concentrations. The amount of MDA present in the sample was calculated and the result was expressed as nmoles of $\mathrm{MDA} / \mathrm{mg}$ of protein.

\subsubsection{Determination of reduced glutathione}

Reduced glutathione was estimated by the method of Ellman, 1959 as described by Kalonia \& Kumar, 2006. This method of estimation involves the use of DTNB chemically known as 5, 5dithiobis- (2-nitrobenzoic acid) which got reduced by $\mathrm{SH}$ groups and generate (per mole of $\mathrm{SH}$ ) 1 mole of 2-nitro-5mercaptobenzoic acid.

An aliquot of supernatant $(1 \mathrm{ml})$ was treated with $4 \%$ sulfosalicylic acid $(1 \mathrm{ml})$ to get precipitated followed by a cold digestion cycle for $1 \mathrm{~h}$ at $4^{\circ} \mathrm{C}$. The sample was then centrifuged for $15 \mathrm{~min}$ at $1200 \mathrm{rpm}$ maintaining a temperature of $4^{\circ} \mathrm{C}$ throughout. To $1 \mathrm{ml}$ of this supernatant, phosphate buffer $(2.7 \mathrm{ml}, 0.1 \mathrm{M}, \mathrm{pH} 8)$ and 5 , 5 dithiobis 2-nitrobenzoic acid (DTNB) $(0.2 \mathrm{ml})$ were added to the processed supernatant. The yellow colour developed in the mixture was read immediately against a reagent blank at $412 \mathrm{~nm}$ wavelength. The outcomes were subjected to calculation employing the standard curve of reduced glutathione and results were expressed in terms of percentage of the control reading.

\subsubsection{Determination of superoxide dismutase}

Superoxide dismutase was determined using the method of Marklund and Marklund, 1974.

The degree of inhibition of autoxidation of pyrogallol at an alkaline $\mathrm{pH}$ by SOD was used as a measure of the enzyme activity. 20 $\mathrm{mg}$ of liver tissue was homogenized in $2 \mathrm{ml}$ of potassium phosphate buffer. The homogenate was centrifuged at $10,000 \mathrm{rpm}$ at 4 ${ }^{\circ} \mathrm{C}$ in a cooling centrifuge for 20 minutes. $100 \mu$ l of supernatant was added to $3 \mathrm{ml}$ of tris $\mathrm{HCl}$ buffer, $\mathrm{pH} 8.5$ followed by $25 \mu \mathrm{l}$ of pyrogallol and then mixed thoroughly. The change in absorbance at $420 \mathrm{~nm}$ was recorded at 1 minute interval for 3 minutes. The increase in absorbance at $420 \mathrm{~nm}$ after addition of pyogallol was inhibited by the presence of SOD. One unit of SOD is described as the amount of enzyme required to cause $50 \%$ inhibition of pyrogallol autoxidation per $3 \mathrm{ml}$ of assay mixture. Results have been expressed in units per mg protein for tissue homogenate.

\subsubsection{Determination of catalase}

Catalase was estimated by the method of Greenwald and Clairborne, 1985. The homogenate was further centrifuged at 10,000 rpm at $4{ }^{\circ} \mathrm{C}$ in cooling centrifuge for 20 minutes. $50 \mu \mathrm{l}$ of supernatant was added to the cuvette containing $2.95 \mathrm{ml}$ of $19 \mathrm{mM} / \mathrm{L}$ solution of $\mathrm{H}_{2} \mathrm{O}_{2}$ prepared in potassium phosphate buffer. The disappearance of $\mathrm{H}_{2} \mathrm{O}_{2}$ was monitored at $240 \mathrm{~nm}$ wavelength at $1 \mathrm{mi}-$ nute interval for 3 minutes. Catalase activity was calculated and result was expressed as nano moles of $\mathrm{H}_{2} \mathrm{O}_{2}$ consumed/minute/mg protein.

\subsection{Statistical analysis}

The results were expressed as mean \pm SEM. Statistical analysis was carried out by ANOVA followed by Dunnet's multiple comparison tests using Graph Pad Prism software version 4.03 (Graph Pad Software Inc. San Diego, California, USA). P values $<0.05$ were considered as statistically significant.

\section{Results \& discussion}

\subsection{Total phenolic content}

The concentration of total phenols was expressed as $\mathrm{mg} / \mathrm{g}$ of extract. The concentration of total phenolic compounds in the extract was presented as gram of Gallic acid equivalent (GA) using an equation obtained from the equation of regression line of standard Gallic acid graph. The total phenolic content present in $70 \%$ aqueous alcoholic extract of Eugenia caryophyllus was found to be $84.7 \pm 0.069 \mathrm{mg} / \mathrm{g}$ ie. $8.47 \mathrm{~g} \pm 0.069 \mathrm{phenol} / 100 \mathrm{~g}$ extract. 


\subsection{Total flavonoid content}

Concentration of flavanoids in extract was expressed in terms of Quercetin equivalent (mg of $\mathrm{Qu} / \mathrm{g}$ of extract). The total flavanoid content present in $70 \%$ aqueous ethanolic extract of Eugenia caryophyllus was found to be $15.37 \pm 1.17 \mathrm{mg} / \mathrm{g}$ of extract.

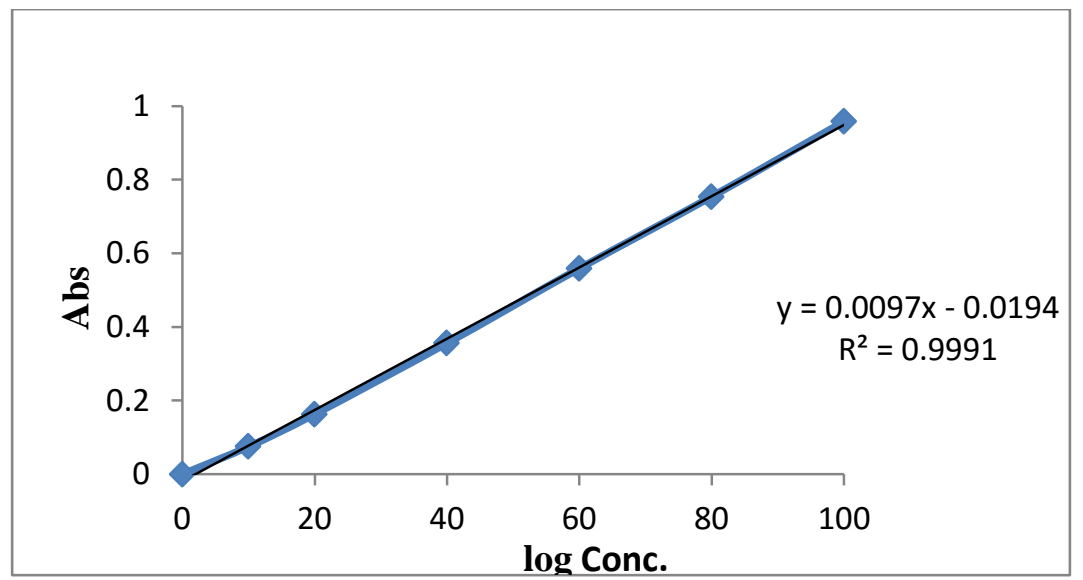

Fig. 1: Total Phenolic Contents of the Hydro-Alcoholic Extract of Eugenia caryophyllus.

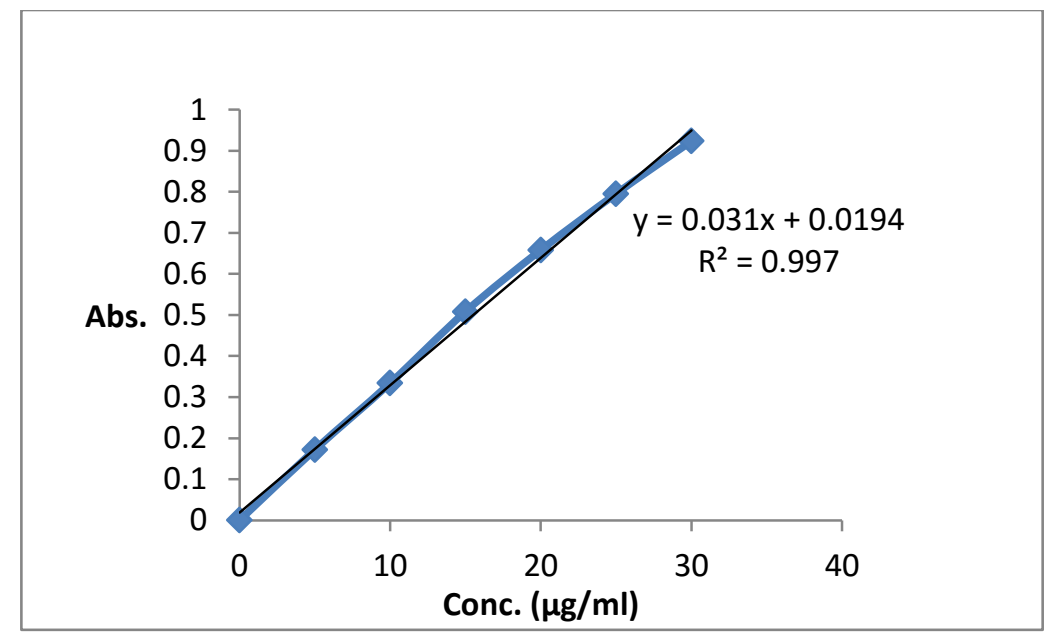

Fig. 2: Total Flavonoid Contents of the Hydro-Alcoholic Extract of Eugenia caryophyllus.

\subsection{DPPH assay}

The figure $3 \& 4$ show the antioxidant activities of hydro-ethanolic extract of Eugenia caryophyllus and the standard ascorbic acid. The free radical scavenging activities of the plant extract are expressed in the form of $\mathrm{IC}_{50}$ value which is inversely proportional to antioxidant activity. $\mathrm{IC}_{50}$ is the concentration of the sample required to scavenge $50 \%$ of free radicals present in the system. From the graph and calculations, it was concluded that the free radical scavenging activity of the plant extract was almost comparable to that of the standard Ascorbic acid.

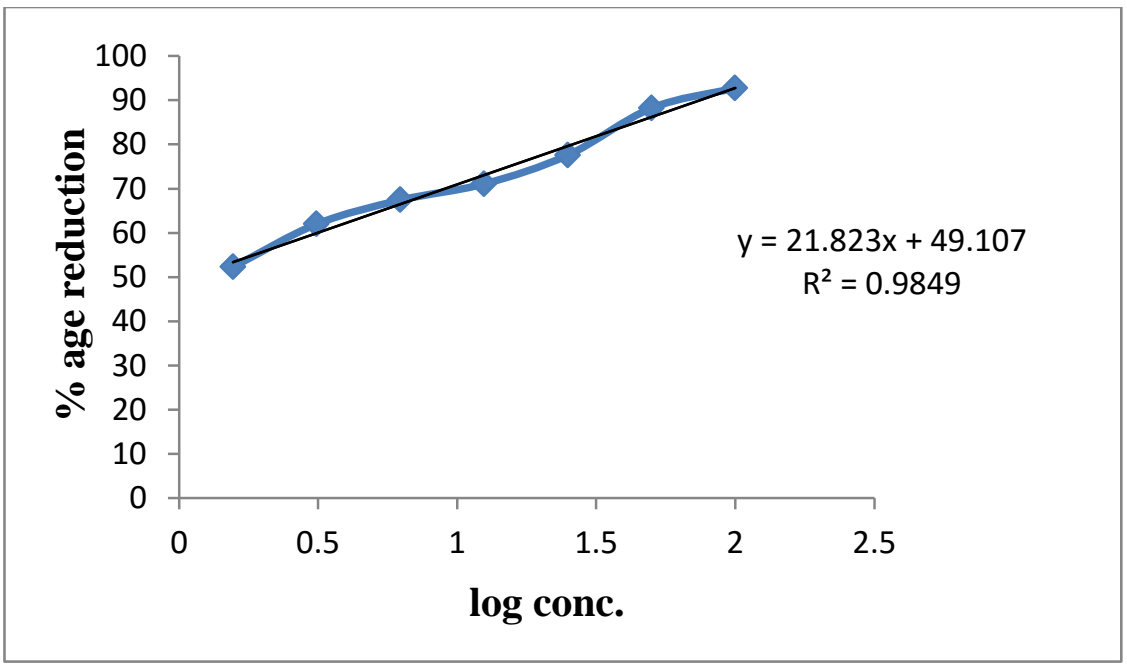

Fig. 3: DPPH Assay of the Hydro-Alcoholic Extract of Eugenia caryophyllus. 


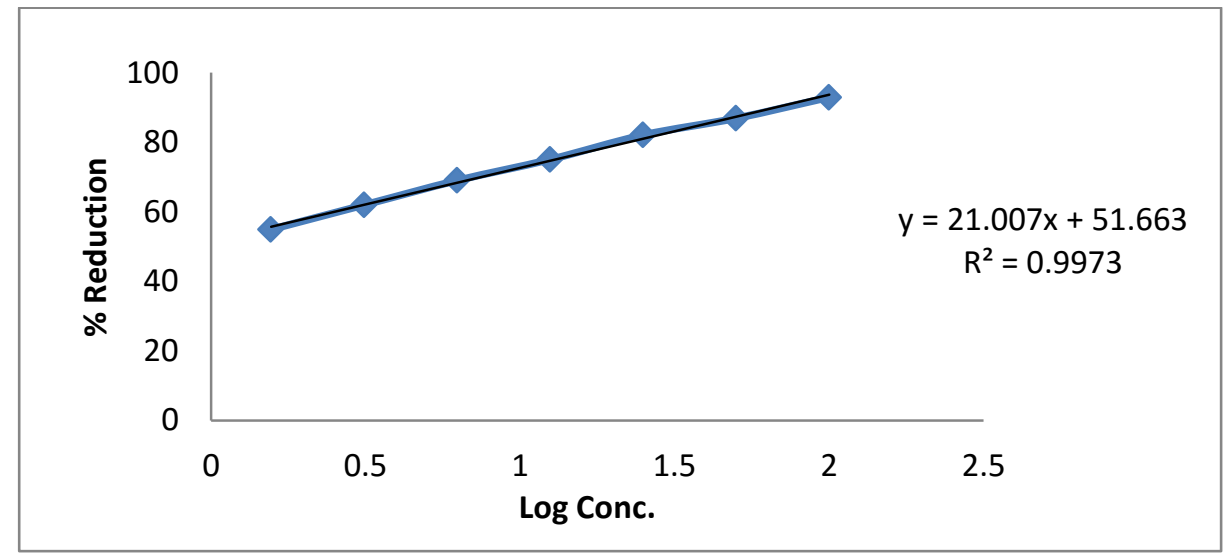

Fig. 4: DPPH Assay for the Standard Ascorbic Acid.

Using the regression co-efficient, the free radical scavenging activity i.e. $\mathrm{IC}_{50}$ of the plant extract was calculated to be $1.098 \mu \mathrm{g} / \mathrm{ml}$ while the IC50 for ascorbic acid was calculated from linear regression analysis and found to be $0.162 \mu \mathrm{g} / \mathrm{ml}$.

\subsection{Estimation of in-vivo anti-oxidant enzymes}

\subsubsection{Effect of the extract on malondialdehyde (MDA)}

Lipid peroxidation was increased in the triton induced \& high fat diet induced rats, as revealed by elevated MDA levels, when compared with the normal control group. The increase in MDA reflects excessive formation of free radicals and activation of lipid peroxidation. Co-treatment with the aqueous ethanolic extract of Eugenia caryophyllus at the dose of $200 \mathrm{mg} / \mathrm{kg}$ significantly decreased the MDA levels with value as $0.79 \pm 0.03 \mathrm{nmol} / \mathrm{mg}$ pr in triton model and $0.38 \pm 0.03 \mathrm{nmol} / \mathrm{mg}$ pr which were almost similar to those of rats receiving the standard drug Atorvastatin with value as $0.82 \pm 0.02 \& 0.41 \pm 0.02 \mathrm{nmol} / \mathrm{mg}$ pr. However the extract at the dose of $400 \mathrm{mg} / \mathrm{kg}$ exhibited the maximum reduction in lipid peroxidation, as depicted by a higher decrease in MDA levels showing value of $0.56 \pm 0.04 \& 0.35 \pm 0.02$ respectively. The results are displayed in the table $1 \& 2$.

Table 1: Effect of Hydro-Alcoholic Extract of Eugenia caryophyllus on In-vivo TBARS, Reduced Glutathione and Superoxide Dismutase in Liver Tissue in Triton Induced Hyperlipidemic Model.

\begin{tabular}{|c|c|c|c|c|c|}
\hline $\begin{array}{l}\text { S.No } \\
\text {. }\end{array}$ & Group & $\begin{array}{l}\text { Total } \\
\text { Protein } \\
(\mathrm{mg} / \mathrm{ml})\end{array}$ & $\begin{array}{l}\text { MDA } \\
\text { (nmole/m } \\
\text { g protein) }\end{array}$ & $\begin{array}{l}\text { GSH } \\
(\mu \mathrm{g} / \mathrm{mg} \\
\text { protein) }\end{array}$ & $\begin{array}{l}\text { SOD } \\
\text { (U/mg } \\
\text { protein) }\end{array}$ \\
\hline 1. & $\begin{array}{l}\text { Group } \\
\text { I }\end{array}$ & $\begin{array}{l}14.58 \pm 1.0 \\
4\end{array}$ & $0.40 \pm 0.02$ & $39.06 \pm 0.96$ & $26.58 \pm 2.01$ \\
\hline 2. & $\begin{array}{l}\text { Group } \\
\text { II }\end{array}$ & $\begin{array}{l}15.32 \pm 1.8 \\
5\end{array}$ & $1.41 \pm 0.04^{\mathrm{a}}$ & $17.52 \pm 0.75$ & $11.80 \pm 0.85^{\mathrm{a}}$ \\
\hline 3. & $\begin{array}{l}\text { Group } \\
\text { III }\end{array}$ & $\begin{array}{l}15.86 \pm 1.0 \\
8\end{array}$ & $\begin{array}{l}0.79 \pm 0.03 \\
b\end{array}$ & $\begin{array}{l}30.30 \pm 1.20 \\
\text { b }\end{array}$ & $18.62 \pm 1.42^{c}$ \\
\hline 4. & $\begin{array}{l}\text { Group } \\
\text { IV }\end{array}$ & $\begin{array}{l}15.22 \pm 0.5 \\
6\end{array}$ & $0.56 \pm 0.04$ & $\underset{b}{35.87 \pm 1.39}$ & $\underset{b}{19.23 \pm 1.38}$ \\
\hline 5. & $\begin{array}{l}\text { Group } \\
\text { V }\end{array}$ & $\begin{array}{l}17.53 \pm 0.8 \\
6\end{array}$ & $\begin{array}{l}0.82 \pm 0.02 \\
b\end{array}$ & $29.25 \pm 1.38$ & $23.50 \pm 1.61^{\mathrm{c}}$ \\
\hline
\end{tabular}

Values are expressed as mean \pm SEM $(n=6)$. ${ }^{a} \mathrm{P}<0.05$ vs Group I and ${ }^{\mathrm{b}} \mathrm{P}<0.05$ vs Group II, ${ }^{\mathrm{C}} \mathrm{P}<0.05$ vs Group III using one way ANOVA followed by Dunnett's test.

Group I: Normal Control: Group II: Triton $100(400 \mathrm{mg} / \mathrm{kg})$. Group III: Triton + hydro-alcoholic extract of Eugenia caryophyllus (200mg/kg B.wt) Group IV: Triton + hydro-alcoholic extract of Eugenia caryophyllus (400mg/kg B.wt), Group V: Triton + standard drug atorvastatin $(10 \mathrm{mg} / \mathrm{kg} \mathrm{b.wt})$
Table 2: Effect of Hydro-Alcoholic Extract of Eugenia caryophyllus on In-vivo TBARS, Reduced Glutathione and Superoxide Dismutase and Catalase in Liver Tissue in HFD Model

\begin{tabular}{|c|c|c|c|c|c|c|}
\hline S.No. & $\begin{array}{l}\text { Gro } \\
\text { up }\end{array}$ & $\begin{array}{l}\text { Total } \\
\text { Protein } \\
(\mathrm{mg} / \mathrm{ml} \\
\text { ) }\end{array}$ & $\begin{array}{l}\begin{array}{l}\text { MDA } \\
\text { (nmoles }\end{array} \\
\text { /mg } \\
\text { protein) }\end{array}$ & $\begin{array}{l}\text { GSH } \\
\text { ( } \mu \mathrm{g} / \mathrm{mg} \\
\text { protein) }\end{array}$ & $\begin{array}{l}\text { SOD } \\
\text { (U/mg } \\
\text { protein) }\end{array}$ & $\begin{array}{l}\text { Catalase } \\
\text { (U/mg } \\
\text { protein) }\end{array}$ \\
\hline 1. & $\begin{array}{l}\text { Gro } \\
\text { up I }\end{array}$ & $\begin{array}{l}21.68 \pm \\
0.77\end{array}$ & $\begin{array}{l}0.32 \pm 0 \\
01\end{array}$ & $\begin{array}{l}26.13 \pm \\
0.96\end{array}$ & $\begin{array}{l}18.69 \pm 1 . \\
98\end{array}$ & $\begin{array}{l}19.99 \pm 0 . \\
82\end{array}$ \\
\hline 2. & $\begin{array}{l}\text { Gro } \\
\text { up } \\
\text { II }\end{array}$ & $\begin{array}{l}23.67 \pm \\
1.85^{\mathrm{a}}\end{array}$ & $\begin{array}{l}0.60 \pm 0 . \\
04^{\mathrm{a}}\end{array}$ & $\begin{array}{l}17.77 \pm \\
0.47^{\mathrm{a}}\end{array}$ & $\begin{array}{l}7.98 \pm 0.5 \\
0^{\mathrm{a}}\end{array}$ & $\begin{array}{l}10.61 \pm 0 . \\
48^{a}\end{array}$ \\
\hline 3. & $\begin{array}{l}\text { Gro } \\
\text { up } \\
\text { III }\end{array}$ & $\begin{array}{l}24.51 \pm \\
0.67^{\mathrm{b}}\end{array}$ & $\begin{array}{l}0.38 \pm 0 \\
03^{\mathrm{b}}\end{array}$ & $\begin{array}{l}20.44 \pm \\
0.67^{\mathrm{b}}\end{array}$ & $\begin{array}{l}14.58 \pm 0 \\
69^{\mathrm{b}}\end{array}$ & $\begin{array}{l}16.00 \pm 0 . \\
46^{\mathrm{b}}\end{array}$ \\
\hline 4. & $\begin{array}{l}\text { Gro } \\
\text { up } \\
\text { IV }\end{array}$ & $\begin{array}{l}24.34 \pm \\
0.56^{\mathrm{b}, \mathrm{c}}\end{array}$ & $\begin{array}{l}0.35 \pm 0 \\
02^{\mathrm{b}, \mathrm{c}}\end{array}$ & $\begin{array}{l}25.93 \pm \\
1.36^{\mathrm{b}, \mathrm{c}}\end{array}$ & $\begin{array}{l}18.54 \pm 1 \\
54^{\text {b,c }}\end{array}$ & $\begin{array}{l}18.36 \pm 0 \\
60^{\mathrm{b}, \mathrm{c}}\end{array}$ \\
\hline 5. & $\begin{array}{l}\text { Gro } \\
\text { up } \\
\text { V }\end{array}$ & $\begin{array}{l}21.11 \pm \\
0.86^{\mathrm{b}}\end{array}$ & $\begin{array}{l}0.41 \pm 0 \\
02^{\mathrm{b}}\end{array}$ & $\begin{array}{l}25.36 \pm \\
1.37^{\mathrm{b}}\end{array}$ & $\begin{array}{l}17.85 \pm 0 . \\
64^{\mathrm{b}}\end{array}$ & $\begin{array}{l}15.84 \pm 0 . \\
28^{\mathrm{b}}\end{array}$ \\
\hline
\end{tabular}

Values are expressed as mean $\pm \operatorname{SEM}(n=6) .{ }^{a} \mathrm{P}<0.05$ vs Group I and ${ }^{\mathrm{b}} \mathrm{P}<0.05$ vs Group II, ${ }^{\mathrm{c}} \mathrm{P}<0.05$ vs Group III using one way ANOVA followed by Dunnett's test.

Group I: standard chow diet: Group II: high fat diet Group III: HFD + hydro-alcoholic extract of Eugenia caryophyllus (200mg/kg B.wt) Group IV: HFD + hydro-alcoholic extract of Eugenia caryophyllus (400mg/kg B.wt), Group V: HFD +standard drug atorvastatin $(10 \mathrm{mg} / \mathrm{kg} \mathrm{b} . \mathrm{wt})$.

\subsubsection{Effect of the extract on GSH levels}

Reduced Glutathione, an endogenous anti-oxidant defence enzyme, plays a prominent role in the defence against free radicals, peroxides and a wide range of xenobiotics \& carcinogens (Abu \& Fouad, 2000). In the present study, the GSH level of tissue homogenate in triton treated group was found to be lowered significantly $(\mathrm{P}<0.001)$ than the GSH level in normal control group. After the scheduled treatment with the extract at dose $200 \mathrm{mg} / \mathrm{kg}$, GSH level was found to be increased in a highly significant manner $(\mathrm{P}<0.001) 30.30 \pm 1.20 \mu \mathrm{g} / \mathrm{mg}$ pr. having comparable efficacy with reference drug Atorvastatin at the dose of $10 \mathrm{mg} / \mathrm{kg}$. (value $29.25 \pm 1.38 \mathrm{ug} / \mathrm{mg}$ pr.). In Table 2, Group II in HFD model depicted significant decrease in reduced glutathione levels in high fat diet induced rats. Administration of the hydro-alcoholic extract of Eugenia caryophyllus increased the levels of glutathione. However out of all the treated groups, the plant extract at the dose of $400 \mathrm{mg} / \mathrm{kg}$ almost completely restored the glutathione to the normal levels as observed in both the models, which suggests maximum in vivo anti-oxidant activity.

\subsubsection{Effect of the extract on SOD levels}

A plethora of studies and research have demonstrated that SOD can play a critical role in reducing internal inflammation and also in neutralizing oxidative stress as well as free radical damage. 
Anti-oxidant activity decreased in triton treated \& HFD group as depicted by decrease in SOD levels. However treatment with hydro-alcoholic extract of Eugenia caryophyllus at the dose of $200 \mathrm{mg} / \mathrm{kg}$ and $400 \mathrm{mg} / \mathrm{kg}$ body weight for 7 days in triton model significantly $(\mathrm{P}<0.001)$ increased the SOD levels with values as $18.62 \pm 1.42 \mathrm{U} / \mathrm{mg}$ pr. \& $19.23 \pm 1.38 \mathrm{U} / \mathrm{mg}$ pr. respectively However, the group receiving Atorvastatin $(10 \mathrm{mg} / \mathrm{kg})$ exhibited the maximum increase in SOD levels with value of $23.50 \pm 1.61 \mathrm{U} / \mathrm{mg}$ pr. The significant fall in the levels of tissue SOD was observed in high fat diet rats (group II) as compared to the control rats (group I). Administration of hydro-alcoholic extract of Eugenia caryophyllus substantially enhanced the levels of SOD when compared with HFD.

\subsubsection{Effect of extract on catalase activity}

As clearly depicted in Table 2, activity of catalase in liver tissue was significantly lowered in rats treated with high fat diet ie. Group II as compared to control group. High fat diet can cause formation of toxic intermediates that can inhibit the activity of anti-oxidant enzymes and cause accumulation of $\mathrm{O}_{2-}$ and $\mathrm{H}_{2} \mathrm{O}_{2}$ which in turn forms hydroxyl radicals (Thampi et al.1991). Administration of hydro-alcoholic extract of Eugenia caryophyllus significantly increased the activity of catalase, when compared with high fat diet fed rats.

\section{Conclusion}

The results of our study clearly demonstrated that hydro-alcoholic extract of Eugenia caryophyllus have significant anti-oxidant potency, as it was able to increase anti-oxidant enzymes and decrease lipid peroxidation. The above studies indicate that this extract is a significant source of natural anti-oxidants which may help in preventing the progress of various oxidative stress induced disorders. The extract may be taken alone or as an adjuvant with other drugs to inhibit the development of oxidative stress.

\section{Acknowledgement}

We remain highly grateful to Dr. J. Girish, Director and Dr. Manoj Goel, CAO, KIET Group of Institutions for his full co-operation, moral support and provided us with all the necessary facilities required to carry out this research work. We are extremely thankful to Dr. Shivakar, Dean, Shridhar University for his moral support and the faculty members for helping us out during research protocol presentations related to the study. We also thank Mr. Kapil for his kind co-operation. We are very highly grateful to Dr. Mohammed Ali, Department of Pharmacognosy, Faculty of Pharmacy, Jamia Hamdard, New Delhi for authenticating our plant material.

\section{References}

[1] Abou Ghalia AH \& Fouad IM (2000) Glutathione and its metabolizing enzymes in patients with different benign and malignant diseases. Clinical Biochemistry 33, 657-662 http://dx.doi.org/10.1016/S0009-9120(00)00181-8.

[2] Cai, L. \& Wu, C. D. (1996) Compounds from Syzygium aromaticum possessing growth inhibitory activity against oral pathogens. Journal of Natural Products 59, 987-90. http://dx.doi.org/10.1021/np960451q.

[3] Chaieb K, Hajlaoui H, Zmantar T, Kahla-Nakbi AB, Rouabhia M, Mahdouani K \& Bakhrouf A (2007) The Chemical Composition and Biological Activity of Clove Essential Oil, Eugenia caryophyllata (Syzigium aromaticum L Myrtaceae) :A Short Review. Phytotherapy Research 21, 501-06 http://dx.doi.org/10.1002/ptr.2124.

[4] Claiborne A. (1985) Catalase activity. In Handbook of Methods for Oxygen Free Radical Research (Greenwald RA, ed) Boca Raton, FL: CRC Press, pp $283-284$
[5] Ellman, G. L. (1959) Tissue sulfhydryl groups. Archive of Bio$\begin{array}{llll}\text { chemistry and } & \text { Biophysics }\end{array}$ http://dx.doi.org/10.1016/0003-9861(59)90090-6.

[6] Kalonia, H. \& Kumar, A. (2006) Protective Effect of Br-16a (Poly Herbal Preparation) on the behavioral and biochemical alterations in sleep disturbed mice (grid suspended over water method). Annals of Neurosciences 13, 94-98. http://dx.doi.org/10.5214/ans.0972.7531.2006.130401.

[7] Kataki MS, Ahmed MZ, Awasthi D, Tomar B., Mehra P, Yadav RS \& Rajak P (2012) In vitro antioxidant profile of Wedelia calandulaceae leaves. Pharmacologia 3, 75-83 http://dx.doi.org/10.5567/pharmacologia.2012.75.83.

[8] Kumar G, Srivastava, a, Sharma, SK \& Gupta Y K (2013) the hypolipidemic activity of Ayurvedic medicine, Arogyavardhini vati in Triton WR-1339-induced hyperlipidemic rats: A comparison with fenofibrate. Journal of Ayurveda and Integrative Medicine, 4, 165-70 http://dx.doi.org/10.4103/0975-9476.118707.

[9] Lowry OH, Rosebrough N J, Farr AL, \& Randall RJ (1951) Protein Measurement with the Folin Phenol Reagent. The Journal of Biological Chemistry, 193, 265-275.

[10] Marklund S \& Marklund G (1974) Involvement of the superoxide anion radical in the autoxidation of pyrogallol and a convenient assay for superoxide dismutase. European Journal of Biochemistry, 47, 469-474. http://dx.doi.org/10.1111/j.1432 1033.1974.tb03714.x.

[11] Mittal M, Siddiqui MR, Tran K, Reddy SP \& Malik AB (2014) Reactive Oxygen Species in Inflammation and Tissue Injury. Antioxidants and Redox Signaling 20, 1126-1167 http://dx.doi.org/10.1089/ars.2012.5149.

[12] Nourooz-Zadeh J, Tajaddini-Sarmadi J, McCarthy S, Betteridge DJ \& Wolf SP (1995). Elevated levels of authentic plasma hydroperoxides in NIDDM. Diabetes, 44, 1054-1058. http://dx.doi.org/10.2337/diab.44.9.1054.

[13] Ohkawa H, Ohishi N \&Yagi K (1979). Assay for lipid peroxides in animal tissues by thiobarbituric acid reaction. Analytical Biochemistry, 95, 351-58. http://dx.doi.org/10.1016/0003-2697(79)90738-3.

[14] Olayinka AA \& Anthony IO (2009) Phyochemical screening and polyphenolic antioxidant activity of aqueous crude leaf extract of Helichrysum pedulanculatum. International Journal of Molecular Science, 10, 46-58.

[15] Poljsak B (2011). Strategies for reducing or preventing the generation of oxidative Stress. Oxidative Medicine and Cellular Longevity, Article ID 194586, http://dx.doi.org/10.1155/2011/194586.

[16] Poljsak B, Šuput D. \& Milisav I (2013). Achieving the Balance between ROS and Antioxidants: When to Use the Synthetic Antioxidants. Oxidative Medicine and Cellular Longevity, Article ID 956792 http://dx.doi.org/10.1155/2013/956792.

[17] Pourgholami MH, Kamalinejad M, Javadi M, Majzoob S. \& Sayyah M (1999) Evaluation of the anticonvulsant activity of the essential oil of Eugenia caryophyllata in male mice. Journal of Ethnopharmacology, 64, 167-71. http://dx.doi.org/10.1016/S03788741(98)00121-4.

[18] Pourmorad F, Hosseinimetr SJ \& Shahadimajd N (2006) Antioxidant activity, phenol and flavanoid contents of some selected Iranian medicinal plants. African Journal of Biotechnology, 6, 11421145.

[19] Singh AK, Dhamanigi SS. \& Asad M (2009) Anti-stress activity of hydroalcoholic extract of Eugenia caryophyllus buds (Clove). Indian Journal of Pharmacology 41, 28-31. http://dx.doi.org/10.4103/0253-7613.48889.

[20] Srivastava KC (1993) Antiplatelet principles from a food spice clove (Syzygium aromaticum L.) Prostaglandins Leukotrienes and Essential Fatty Acids 48, 363-372. http://dx.doi.org/10.1016/09523278(93)90116-E.

[21] Thampi BS, Manoj G, Leelamma S \& Menon VG (1991) Dietary fibre and lipid peroxidation: effects of dietary fibre on levels of lipids and lipid peroxides in high fat diet. Indian Journal of Experimental Biology 29, 563-67.

[22] Zorov DB, Juhaszova M, \& Sollott SJ (2014) Mitochondrial reactive Oxygen Species (ROS) and ROS-Induced ROS Release. Physiology Reviews 94, 909-950 http://dx.doi.org/10.1152/physrev.00026.2013. 